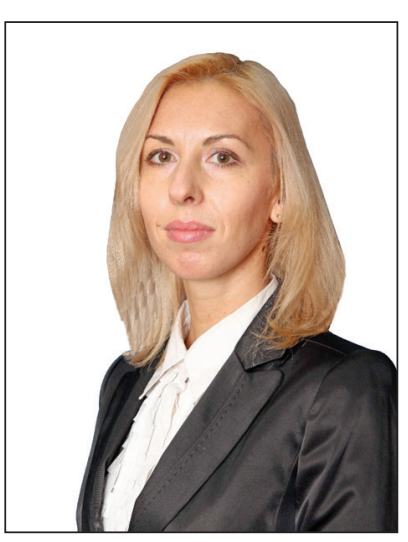

\title{
Сидоренко Ольга Олександрівна,
}

кандидат юридичних наук, асистент кафедри теорії держави і права, Начіональний юридичний університет імені Ярослава Мудрого, Україна, м. Харків e-mail:Sydorenko1200@gmail.com ORCID 0000-0003-0485-6431

\section{doi: 10.21564/2414-990x.141.131531 \\ YAK 340.114.5:340.155.8}

\section{ЗАГААЬНОТЕОРЕТИЧНИЙ АНААІЗ ПРАВОВОЇ СВІАОМОСТІ ЯК КАТААІЗАТОРА РОЗВИТКУ ПРАВОВОЇ СИСТЕМИ УКРАЇНИ}

Розглянуто зміст поняття правової свідомості з огляду на сучасні наукові напрацювання з иієї проблеми. Проаналізовано взаємозв'язки правосвідомості та правової системи у контексті євроінтегращійних процесів в Україні. Аргументовано висновок: прощеси, які відбуваються в суспільстві, незмінно впливають на правову свідомість та розвиток нових галузей права. Подальший розвиток правової системи України та набуття нею якісно нових властивостей, які б сприяли розвитку в державі громадянського суспільства та утвердженню верховенства права, можливі лише у контексті розвитку правової свідомості.

Ключові слова: правова свідомість; правова система; громадянське суспільство; система права; структура системи права; предмет правового регулювання; метод правового регулювання.

Сидоренко О. О., кандидат юридических наук, ассистент кафедры теории государства и права, Национальный юридический университет имени Ярослава Мудрого, Украина, г. Харьков.

e-mail : Sydorenko1200@gmail.com ; ORCID 0000-0003-0485-6431

Общетеоретический анализ правового сознания как катализатора развития правовой системы Украины

Рассматривается содержание понятия «правовое сознание» с точки зрения современных научных наработок по этой проблеме. Анализируются взаимосвязи правового сознания и правовой системь в контексте евроинтеграционных процессов в Украине. Аргументирован вывод: процессы, которые происходят в обществе, неизбежно влияют на правовое сознание и развитие новых отраслей права. Дальнейшее развитие правовой системы Украины и приобретение ею качественно новых свойств, которые бы способствовали развитию в государстве гражданского общества и утверждению верховенства права, возможны только в контексте развития правового сознания.

Ключевые слова: правовое сознание; правовая система; гражданское общество; система права; структура системы права; предмет правового регулирования; метод правового регулирования. 
Постановка проблеми. Розвиток правової системи України традиційно є пріоритетним напрямком досліджень сучасної науки теорії держави і права. Генеза правової системи не може відбуватись поза трансформаціями та змінами на рівні іï окремих елементів. Система права є регулятивним ядром правової системи, що формується, базуючись на правовій ідеології певної держави й одночасно виступаючи нормативною основою поведінки у сфері права. Діалектика компонентів правової реальності відбувається за рахунок відбиття їх у свідомості людини та втілення через даний процес в інших юридичних феноменах. Але водночас не слід абстрагуватись від генеративної ролі правової свідомості щодо компонентного складу правової системи, що в подальшому і забезпечує іiі інтегрування. Істотним фактором, який підвищує теоретичну актуальність даної теми, є те, що основна увага на теоретичному рівні здебільшого приділялась нормативній складовій правової системи, що дещо штучно відсувало питання, пов'язані з розвитком правосвідомості, на другий план. Утім, практика правотворчих процесів в Україні довела потребу у спеціальних юридичних дослідженнях питань взаємозв'язку між динамікою правової свідомості та розвитком правової системи в цілому.

Реалізація правових норм та підвищення ефективності правового регулювання зумовлюють потребу у вивченні всіх чинників, які сприяють нормальному розвитку правового життя суспільства та правових відносин. Одним з них є правова свідомість, оскільки так само, як функціонування правової системи неможливе без суб'єктів права, так і існування самих суб'єктів права не можна уявити відокремлено від правової свідомості. Досить часто недієвість та неефективність правового регулювання пояснюються не лише низьким рівнем чинних нормативно-правових актів, а й фактором відторгнення правовою свідомістю суспільства даних правових норм або цілих правових інститутів.

Метою цієї статті є дослідження з теоретико-правових позицій змісту поняття та аналіз взаємозв'язків правової свідомості та правової системи у векторі євроінтеграційних процесів в Україні.

Аналіз останніх досліджень $і$ публікащій. Дослідженням проблематики даної наукової статті займалися: С. С. Алексєєв (S. S. Aleksieiev), П. П. Баранов (Р. Р. Baranov), В. Л. Васильєв (V. L. Vasyliev), В. В. Копейчиков (V. V. Kopeichykov), В. М. Коробка (V M. Korobka), В. В. Лазарєв (V. V. Lazariev), O. В. Малько (О. V. Malko), М. Н. Марченко (M. N. Marchenko), M. I. Матузов (M. I. Matuzov), В. В. Пашутін (V. V. Pashutin), П. М. Рабинович (P. M. Rabynovych), В. П. Сальников (V. P. Salnykov), О. Ф. Скакун (O. F. Skakun), С. С. Сливка (S. S. Slyvka), С. Р. Станік (S. R. Stanik), В. I. Темченко (V. I. Temchenko) та інші. Водночас наукових праць, які б розкривали згадані вище категорії як взаємозалежні, майже не спостерігається.

Виклад основного матеріалу. Правова свідомість досліджується як категорія правознавства, що знаходиться у нерозривному зв'язку з правом, входить як елемент до правової системи. Традиційний інтерес до цієї проблеми пояснюється незавершеністю розробок функціонування правової свідомості 
в суспільстві, не визначено також шляхи формування, недостатньо досліджено питання стосовно маніпуляції суспільною свідомістю.

Науковці приділяють велику увагу поняттю правової свідомості, зважаючи на доволі значний i вплив на якість правового регулювання, побудову громадянського суспільства. Особливо це стало помітно в радянський та пострадянський періоди. Через широкий спектр філософсько-правових питань, які пов’язані з правосвідомістю, зокрема те, що вона охоплює життєво важливі суспільні категоріі, такі як право та свідомість, у літературі немає досі однозначного визначення поняття правової свідомості.

Визначення правосвідомості передбачає перш за все розгляд поняття «свідомість», позаяк правова свідомість є похідною формою свідомості. А свідомість, у свою чергу, може бути розглянута з різних боків. Свідомість - це одне з фундаментальних понять філософії, психології, соціології, яке характеризує важливий системний компонент людської психіки. Функціонування свідомості забезпечує людині можливість створювати знання про зв'язки, відносини, закономірності об'єктивного світу, встановлювати цілі та розробляти плани, які представляють їі діяльність, регулювати та контролювати емоційні, раціональні та предметно практичні відносини з дійсністю, визначити ціннісні орієнтири свого буття та поліпшити умови свого існування [1, с. 632-633].

Свідомість людини в психології - це сформована в процесі суспільного життя вища форма психічного відображення дійсності в вигляді суб'єктивної моделі навколишнього світу в формі словесних понять та чуттєвих образів. Властива лише людині свідомість є продуктом суспільно-історичного розвитку людства. Свідомість людини характеризується активністю, спрямованістю на певний об'єкт, здатністю до самоспостереження і рефлексії, різним ступенем ясності тощо [2, с. 316]. Свідомість з точки зору філософії - це специфічна форма ідеального відображення і духовного освоєння дійсності. Це вищий вид духовної активності особистості, яка виявляється в здатності відображати реальність у формі почуттів та образів мислення, які передбачають практичну діяльність і повідомляють їх цілеспрямований характер [3, с. 78].

В юридичній літературі не існує усталеного визначення правової свідомості. Свого часу I. Є. Фарбер (радянський період) визначив правову свідомість як сукупність правових поглядів та почуттів, які наділені нормативним характером і включають в себе як знання правових явищ, так і оцінку з точки зору класової (або загальнонародної) справедливості, а також нові правові вимоги, які відображають економічні та політичні потреби й інтереси суспільного розвитку [4, с. 204-205]. На думку О. А. Лукашевої, правосвідомість - це погляди, уявлення, думки, почуття, настрої, які виражають розуміння необхідності встановлення та функціонування визначеного правового порядку в суспільстві [5, с. 17].

Формулюючи поняття правосвідомості, О. Ф. Скакун утримується від намагання навести усі характеристики емоційного чи розумового спрямування і зазначає, що правосвідомість - це система почуттєвих і мисленневих образів комунікативно-вольової спрямованості, через які відбувається безпосереднє 
і опосередковане сприйняття правової реальності - ставлення до чинного, минулого і бажаного права, до діяльності, пов'язаної з правом, до правових явищ і поведінки людей у сфері права [6, с. 96].

Так, К. Т. Бельський вказує, що правосвідомість - це категорія історичного матеріалізму для визначення тої форми суспільної свідомості, яка відображає крізь призму класових інтересів суперечності суспільного буття, пов'язані 3 нерівністю, і яка має вираження у системі правових ідей, теорій, поглядів та психологічних форм, які мають свій прояв у загальнообов'язкових правових нормах, в груповій, індивідуальній та суспільній правосвідомості [7, с. 19].

О. А. Жидовцева правосвідомість визначає як особливу сферу свідомості, що відбиває правову дійсність у формі юридичних знань та оцінного ставлення до права і практики його реалізації, соціально-правових установок і ціннісних орієнтацій, що регулюють поведінку в юридично значущих ситуаціях [8, с. 308]. Загалом таке визначення правильне, якщо споглядати суспільну значущість правосвідомості за дійсних обставин, тобто беручи до уваги лише так зване «сьогодні», без урахування подальшої еволюції правових відносин. Однак такий підхід до означення правосвідомості унеможливлює вдосконалення у майбутньому цієї ж правової дійсності за рахунок внутрішнього бажання носіїв правосвідомості (індивідів, соціальних груп, народів тощо) змінити правовий стан речей, покращивши його.

B. І. Тимошенко розглядає правосвідомість як сукупність правових уявлень, поглядів, оцінок, концепцій, теорій, доктрин, що виражають суб'єктивне ставлення окремо взятих осіб, груп або суспільства загалом до правової системи залежно від визнання або заперечення цінності права, тобто його справедливості, сили та ефективності [9, с. 41]. За такого підходу до значення цього явища, залежно від визнання або заперечення цінності права, виникає запитання: чи розглядати правосвідомість як позитивне явище? 3 позицією В. І. Тимошенка можна погодитися у разі, якщо в його визначенні розглядати не право загалом, а тільки об’єктивне юридичне право. Тоді правосвідомість виражає суб'єктивне ставлення її носіїв до сформованих та/або санкціонованих державою правових норм, які залежно від типу правової системи, від притаманного такій державі режиму, декларують чи нехтують загальноправовими принципами, що захищають природну та соціальну сутність людини.

Науковці-правники неодноразово наголошували на тому, що розуміння права як системи юридичних норм (системної субстанції) передбачає дослідження як самих цих норм, так і цілого комплексу правових елементів та явищ, які пов'язують ці норми: не лише її структурних складників (галузей права, інститутів, підгалузей права), предмета й метода правового регулювання, але й тих сил внутрішньої самоорганізації системи, які перетворюють сукупність правових норм у систему [10, с. 365]. Звернення ж до інтегративних властивостей правової свідомості як відносно незалежного елемента правової системи дає можливість упевнено констатувати визнання саме правосвідомості як подібного системоутворюючого чинника. Оскільки динаміка суспільних відносин на 
сучасному етапі характеризується стрімкістю та різновекторністю, стає можливим твердження про те, що структуризація права за галузями здійснюється насамперед на рівні свідомості, і тільки після цього стає можливим створення правових норм і їх галузеве відокремлення [11, с. 10]. Тобто певна усталеність системи права зазнає впливу з боку динамічного розгалуження предметів правового регулювання внаслідок виникнення нових та видозміни наявних соціальних зв’язків. Тому формування нових галузей права насамперед зумовлене фактичними відносинами та, відповідно, суттєвими блоками фактичних норм, які складаються для їх регулювання. Зважаючи на вищевикладене, нові галузі права (в тому числі їх відокремлення від наявних) насамперед складаються через їх усвідомлення як таких на побутовому та доктринальному рівні. Під критеріями галузоутворення розуміють ознаки, властивості, наявність яких дає змогу зробити висновок, що певне правове утворення (інститут, підгалузь тощо) досягло у своєму розвитку статусу самостійної галузі в системі права [12, с. 11]. Однак процес накопичення систематизуючих факторів є складним питанням. Адже немає вимірювального приладу, за допомогою якого можна було б визначити готовність нормативного масиву перейти у ранг самостійної галузі. Тому, на думку В. С. Бєлих, і на загальнотеоретичному, і на галузевому рівнях дослідження потрібен набір критеріїв такої оцінки [13, с. 11; 11, с. 10]. Натомість через відсутність чітких показників їх обгрунтування також набуває умоглядності.

Правосвідомість як соціальне явище проявляє себе у безпосередньому функціонуванні, поза яким воно не існує. Завдяки функціям правосвідомість (суспільна, групова, індивідуальна) своєчасно забезпечується новими правовими цінностями, які визначають ефективну організацію і перспективний розвиток правової системи. Становлення правової системи України відбувається 3 моменту проголошення i незалежності на базі правосвідомості, яка характеризується як динамічністю, так і стабільністю, новаціями і традиціями. Як правило, новаційна правосвідомість - соціал-реформістська, революційна, а традиційна - орієнтована на відтворення існуючих соціальних форм, політико-правових інститутів, опір новим ідеям і принципам. Нерідко формуються правові симбіози, які включають елементи старих і нових психологічних переживань та ідеологічних обставин. Вимагаючи нових правових ціннісних орієнтацій (установок), суб'єкти права змушені або використовувати традиційні стандарти правосвідомості, або миритися з ними.

Відомо, що правосвідомість є одним з найбільш консервативних елементів правової системи. Вона болісно розлучається з усталеними уявленнями про правову реальність (частина населення звикла до дрібної регламентації державою їх життя, що існувала за радянських часів). Для подолання усталених правових поглядів і забобонів у суспільстві, яке трансформується, необхідно значно більше часу, ніж для проведення певної «ревізії нормативно-правових актів, приписи яких не відповідають потребам і запитам сучасної соціальної практики [14, с. 95]. 
Парадигмою юридичної науки нині є виокремлення галузей права через предмет та метод правового регулювання. Характеристика предмета правового регулювання, а отже, і галузі права, залежать від структуризації суспільних відносин, що складаються у реальному житті на конкретному історичному етапі. Своєю чергою, структуризація суспільного життя здійснюється залежно від необхідності та реалізованого способу виробництва, обміну та споживання, форм власності, механізму господарювання, ступеня державного втручання (або регулювання) в економічні відносини [15, с. 31]. Це означає, що хоча кристалізація галузей права остаточно здійснюється у площині правової доктрини, але важливо розуміти, що вона також обумовлена безліччю неюридичних детермінант, які переводяться на правовий рівень через правосвідомість. Отже, група соціальних, економічних відносин, до того як стати предметом правового регулювання, виокремлюються з усього масиву соціальних зв'язків та зіставляються у свідомості індивідів з їх фактичним упорядкуванням на офіційному та неофіційному рівні. Зазначимо, що кінетика деяких із них є настільки нелінійною, що фактичні (неофіційні) норми значно переважають за кількістю та подекуди за якістю. Інакше кажучи, для формування нової галузі права певні суспільні відносини повинні сприйматися особами як досить поширені, подібні та такі, що потребують законодавчого врегулювання. І лише після цього набуває сенсу підведення наукової аргументації під утворення нової галузі права. Інакше це виглядає штучним та втрачає будь-який праксеологічний аспект. Також на увагу заслуговують і зміни в усвідомленні змісту категорії «предмет регулювання». Зазвичай, коли говорять про суспільні відносини, мають на увазі економічні відносини, що утворюють базис суспільства. Але поняття суспільних відносин ширше і включає всі відносини людей у суспільстві [16, с. 103]. Предметом же правового регулювання стають не всі вони, а виключно найбільш важливі, найзначущі. Та безсумнівно, що й сама категорія «найзначущі суспільні відносини» $є$ оціночною, у зв'язку з чим вона повинна бути усвідомленою та сформованою розумово на основі соціально-економічних детермінант. Як писав відомий теоретик права С. С. Алексєєв, до предмета правового регулювання не включаються техніко-економічні відносини, пов'язані безпосередньо з продуктивними силами [17, с. 100]. Еволюція ж економічних відносин суттєво вплинула на цей постулат, підтвердженням чого виступають у тому числі Правила ISO або правила захисту інформації в ЕOM (комп'ютерах), а також їх системах, мережах. 3 огляду на викладене, інтегративні властивості правосвідомості виявляють себе в тому числі в структуризації системи права на основі переведення предмета правового регулювання з побутового рівня (фактичні суспільні відносини) на доктринальний, що згодом втілюється на нормативному рівні (наприклад, у процесі кодифікації) та підлягає реалізації, яка становить вже зміст юридичної практики. Значення правосвідомості в окресленні методів правового регулювання як галузеутворюючого критерію складно переоцінити. Бо саме домінування певних засобів впливу, зрештою, і визначає ставлення більшості населення до права. Абстрагуючись від факту, що окремі галузі права 
традиційно базуються на імперативному методі регулювання суспільних відносин, слід визнати тенденцію до розширення застосування інших методів, яка стає все наочнішою у західних демократичних країнах. У наукових публікаціях пострадянського простору у контексті цього стали висвітлюватися положення про те, що «в демократичному суспільстві домінують галузі права з диспозитивними методами регулювання, в авторитарних та тоталітарних державах більшу цінність мають галузі з імперативним регулюванням» [18, с. 305]. Сьогодення знаменується й розширенням меж застосування інших методів регулювання (крім імперативного) в окремих галузях права. Але зазначена тенденція, на жаль, мало стосується України, і використання імперативних методів регулювання все ще залишається домінуючим. Інколи відбувається спроба законодавця нібито надати адресату норм права більше свободи за рахунок більш широкого використання відносно визначених норм. Слід визнати, що це насправді не змінює основного методу регулювання, а лише призводить до підміни понять. I. Л. Заморська, здійснюючи спробу співвіднесення диспозитивних та відносно визначених норм права, доходить висновку, що, попри всю близькість (а в багатьох моментах і почасти тотожність) цих категорій, диспозитивні норми права відображають внутрішню сутність специфічного типу врегульовуваних правом суспільних відносин, що грунтуються на юридичній свободі суб'єктів правовідносин і є похідними від диспозитивного методу правового регулювання. Натомість відносно визначені норми права відображають зовнішню форму закріплення та вираження особливого виду норм права, що передбачають нормативно окреслену свободу вибору сторонами правовідносин певного варіанту поведінки. Відносно визначені норми права є похідними від внутрішньої структури норм права та видів іi структурних компонентів [19, с. 11]. Вони надають скоріше уявну, ніж реальну свободу вибору суб'єктам правовідносин, що також може мати місце та бути, безумовно, корисним з урахуванням мети правового регулювання. Проте структурованість та зрозумілість нормативних регуляторів, тобто й їх розумово-емоційне сприйняття, безпосередньо залежить і від застосовуваного правотворцем методу правового регулювання з його чіткою кристалізацією в усвідомленні як законодавця, так і адресата правового припису, що, відповідно, накладатиме відбиток на правову поведінку. Ще один аспект, вартий уваги, полягає в надто обмеженому використанні у вітчизняній юриспруденції заохочувального методу регулювання суспільних відносин, при тому що в країнах Західної Європи, США, Канаді тощо навіть в адміністративному та кримінальному праві правові засоби, які характеризують даний метод, використовуються набагато ширше, не просто надаючи особі свободу вибору, а стимулюючи правомірний варіант поведінки або ж навіть виправлення після неправомірної. Зокрема, О. Г. Варич робить наголос на ролі договірно-заохочувального методу регулювання економічних відносин, змістом якого є нормативно встановлене стимулювання діяльності суб'єктів економічних відносин, що відповідає не лише правовим вимогам, а й вимогам, установленим за погодженням сторін на договірних засадах [20, с. 7]. Україна ж взяла курс 
на використання здебільшого імперативних підходів у регулюванні, і цей тренд залишається незмінним навіть з урахуванням здійснюваних реформ. Процес кодифікації норм процесуального права держав-членів СС зустрічає на шляху певні перешкоди: форми здійснення правосуддя в кожній країні мають особливості, свої національні традиції, що для громадян інших країн викликає значні труднощі. У цьому криється необхідність зближення національних правових систем, у тому числі тих, що належать до різних сімей права [21, с. 149].

Правова свідомість на відміну від інших явищ правового життя відіграє важливу роль у процесі реалізації функцій правової системи. Всі суб'єкти правовідносин є носіями певної правової свідомості, яка проявляється у формах індивідуальної чи колективної правової свідомості. У цьому контексті неприйнятним є висловлення про те, що органи державної влади та органи місцевого самоврядування діють у суто механічний спосіб, реалізуючи ті формальні й матеріальні вимоги, які визначені на рівні законодавства. Підтримуємо погляд науковців, що це істотно спрощує процес наукової інтерпретації процесу реалізації повноважень державного управління, який багато про це писав [22]. Оскільки навіть якщо цілком ототожнити діяльність органів державної влади та їх посадових осіб з переліком вимог нормативно-правових актів, які регламентують порядок і організацію цієї діяльності, то все одно не можна визнати того, що в процесі прийняття та реалізації управлінських рішень надзвичайно важливим фактором впливу є суб'єктивне сприйняття посадовими особами та державними службовцями тих обов’язків, прав і повноважень, що на них покладаються [23]. Тому, як зауважує С. Погребняк, усі процеси розвитку й реалізації державної влади повинні вивчатись у контексті питань праворозуміння, а також того, в якому стані перебуває правова свідомість та які правові цінності у ній домінують [24, с. 92-93]. А якщо аналізувати поведінку і діяльність індивідуальних суб'єктів права, то в цьому аспекті вплив правової свідомості є ще більшим, оскільки саме на рівні правової свідомості відбувається відображення правової дійсності (адекватне або деформоване), яке по суті визначає тип поведінки окремих індивідів. У цьому сенсі слід визнати, що саме рівень адекватності відтворення правової дійсності на рівні правової свідомості є запорукою правопорядку.

Наостанок підкреслимо, що правосвідомість безпосередньо формується в самій людині та фактично із самою людиною. Вона проходить разом із нею шлях розвитку, у цьому контексті можна провести аналогію зі становленням особистості. I більше того, людина як основа природнього та соціального світу, його розвитку, формує ідеї правового поля, тобто відображає завдяки своїй правосвідомості засади правової дійсності навколо себе.

Висновки. Варто підтримати теоретико-правову позицію щодо правосвідомості як однієї з форм свідомості, яка полягає у ставленні людини до навколишнього світу (до права), причому з різних ракурсів. Правосвідомість перебуває у тісному взаємозв’язку з усіма без винятку підсистемами правової системи та з ㄲï найважливішими функціями. На сучасному етапі стає очевидною необхідність переосмислення окремих парадигм юриспруденції, що виражається 
у зміні акцентів загальновизнаних критеріїв поділу права на галузі, а також навіть в обгрунтуванні доцільності їх розширення. Каталізатором окреслених процесів виступає стрімка динаміка суспільних відносин, але фактичний стан речей набуває юридичного сенсу лише з моменту його відбиття у правосвідомості, що робить можливим переведення фактів реального життя у передумови для формування нових галузей права. Також сучасне інформаційне суспільство характеризується наявністю великого обсягу інформації, який не може сприйняти окремо узятий індивід. Процеси, які відбуваються в суспільстві, незмінно впливають на правову свідомість. Подальший розвиток правової системи України та набуття нею якісно нових властивостей, які б сприяли розвитку в державі громадянського суспільства та утвердженню верховенства права, можливі лише у контексті розвитку правосвідомості як окремих громадян, так і суспільства в цілому.

Потребують подальших досліджень питання, яким чином інформаційна цивілізація перетворює соціокультурний простір, формуючи нову правову свідомість.

\section{Список літератури:}

1. Новейший философский словарь / сост. А. А. Грицанов. Минск : Изд-во В. М. Скакун, 1998. 896 c.

2. Психологічна енциклопедія / автор-упорядник О. М. Степанов. Київ : Академвидав, 2006. $424 \mathrm{c}$.

3. Спиркин А. Г. Сознание и самосознание. Москва : Политиздат, 1972. 276 с.

4. Фарбер И. Е. Правосознание как форма общественного сознания. Москва : Юрид. лит., 1963. 205 c.

5. Лукашева Е. А. Социалистическое правосознание и законность. Москва : Юрид. лит., 1973. 343 c.

6. Скакун О. Ф. Теорія права і держави : підручник. 4-те вид., допов. і перероб. Київ : Алерта, 2013. 524 с.

7. Бельский К. Т. Формирование и развитие социалистического правосознания : монография. Москва : Высшая школа, 1982. 183 с.

8. Жидовцева О. А. Структура та функції професійної правосвідомості. Форум права. 2012. № 1. C. 307-312. URL: http://nbuv.gov.ua/j-pdf/FP_index.htm_2012_1_48.pdf.

9. Тимошенко В. І. Визначальні фактори правової свідомості. Право Украйни. 2008. № 6. C. $41-46$.

10. Аверин А. В. Правопонимание и конкретизация законодательства. Конкретизация законодательства как технико-юридчческий прием нормотворческой, интерпретационной, правоприменительной практики. Нижний Новгород : Нижегородская академия МВД России, 2008. С. 363-374.

11. Дуднік Р. М. До проблеми виокремлення системоутворюючих чинників, що впливають на процес формування нових галузей українського права. Право і суспільство. 2015. № 4. С. 8-12.

12. Головина А. А. К вопросу о понятии критериев отраслеобразования в системе российского права, их теоретическом и практическом значении. Право и государство : теория и практика. 2011. № 6. С. 12-14.

13. Белых В. С. Понятие банковского права и его место в системе права России. Государство и право. 2011. № 4. С. 5-13.

14. Скакун О. Правосознание в правовой системе Украины : эволюционные особенности, профессиональное и региональное измерение. Право Украины. 2013. № 1. С. 93-116. 
15. Дуднік Р. М. Ознаки галузей українського права. Науковий вісник Херсонського державного університету. 2015. Вип. 2. Т. 1. С. 29-32.

16. Строгович М. С. Уголовно-процессуальное право в системе советского права. Советское государство и право. 1957. № 4.

17. Алексеев С. С. О теоретических особенностях классификации отраслей советского права. Советское государство и право. 1957. № 7.

18. Бабенко А. Н. Аксиологические причины правотворческих ошибок. Правотворческие ошибки: понятие, виды, практика и техника устранения в постсоветских государствах : материалы межд. науч.-практ. круглого стола (Москва, 29-30 мая 2008 г.). Москва : Проспект, 2009. C. $304-326$.

19. Заморська Л. І. Відносно визначені норми права: поняття, структура, функції : автореф. дис. ... канд. юрид наук. Одеса, 2009. 24 с.

20. Варич О. Г. Економічні функції сучасної держави : природа, зміст, тенденції розвитку в Україні : автореф. дис. ... канд. юрид наук. Київ, 2006. 22 с.

21. Сидоренко О. О. Процесуальні норми права : поняття, особливості, різновиди: монографія. Харків : Право. 2014. 192 с.

22. Цвєтков В. В., Горбатенко В. П. Демократія - Управління - Бюрократія: в контексті модернізації українського суспільства: монографія. Київ : Ін-т держави і права ім. В. М. Корецького НАН України. 2001. С. 177-270.

23. Цвєтков В. В., Селіванов В. М., Скрипнюк О. В. Державне управління і політика : монографія. Київ : Абрис. 2006. С. 83-98.

24. Погребняк С. Значення основоположних принципів права для формування і розвитку правової державності. Вісник Академї правових наук України. 2008. № 3 (54). С. 92-93.

\section{References:}

1. Hrytsanov, A.A. (1998). Noveishyi fylosofskyi slovar. Mynsk: Yzd-vo V. M. Skakun [in Russian].

2. Stepanov, O.M. (2006). Psykholohichna entsyklopediia. Kyiv: Akademvydav [in Ukrainian].

3. Spyrkyn, A.H. (1972). Soznanye y samosoznanye. Moscow: Polytyzdat [in Russian].

4. Farber, Y.E. (1963). Pravosoznanye kak forma obshchestvennoho soznanyia. Moscow: Yuryd. lyt. [in Russian].

5. Lukasheva, E.A. (1973). Sotsyalystycheskoe pravosoznanye y zakonnost. Moscow: Yuryd. lyt. [in Russian].

6. Skakun, O.F. (2013). Teoriia prava i derzhavy. Kyiv: Alerta [in Ukrainian].

7. Belskyi, K.T. (1982). Formyrovanye y razvytye sotsyalystycheskoho pravosoznanyia. Moscow: Visshaia shkola [in Russian].

8. Zhydovtseva, O.A. (2012). Struktura ta funktsii profesiinoi pravosvidomosti. Forum prava, 1, 307-312. URL: http://nbuv.gov.ua/j-pdf/FP_index.htm_2012_1_48.pdf [in Ukrainian].

9. Tymoshenko, V.I. (2008). Vyznachalni faktory pravovoi svidomosti. Pravo Ukrainy, 6, 41-46 [in Ukrainian].

10. Averyn, A.V. (2008). Pravoponymanye y konkretyzatsyia zakonodatelstva. Konkretyzatsyia zakonodatelstva kak tekhnyko-iurydycheskyi pryem normotvorcheskoi, ynterpretatsyonnoi, pravoprymenytelnoi praktyky. Nyzhnyi Novhorod: Nyzhehorodskaia akademyia MVD Rossyy, S. 363374 [in Russian].

11. Dudnik, R.M. (2015). Do problemy vyokremlennia systemoutvoriuiuchykh chynnykiv, shcho vplyvaiut na protses formuvannia novykh haluzei ukrainskoho prava. Pravo i suspilstvo, 4, 8-12 [in Ukrainian].

12. Holovyna, A.A. (2011). K voprosu o poniatyy kryteryev otrasleobrazovanyia v systeme rossyiskoho prava, ykh teoretycheskom y praktycheskom znachenyy. Pravo y hosudarstvo: teoryia y praktyka, 6, 12-14 [in Russian]. 
13. Belyh, V.S. (2011). Poniatye bankovskoho prava y eho mesto v systeme prava Rossyy. Hosudarstvo y pravo, 4, 5-13 [in Russian].

14. Skakun, O. (2013). Pravosoznanye v pravovoi systeme Ukraynы: эvoliutsyonnые osobennosty, professyonalnoe y rehyonalnoe yzmerenye. Pravo Ukrainy, 1, 93-116 [in Russian].

15. Dudnik, R.M. (2015). Oznaky haluzei ukrainskoho prava. Naukovyi visnyk Khersonskoho derzhavnoho universytetu, Issue 2, Vol. 1, 29-32 [in Ukrainian].

16. Strohovych, M.S. (1957). Uholovno-protsessualnoe pravo v systeme sovetskoho prava. Sovetskoe hosudarstvo y pravo, 4 [in Russian].

17. Alekseev, S.S. (1957). O teoretycheskykh osobennostiakh klassyfykatsyy otraslei sovetskoho prava. Sovetskoe hosudarstvo y pravo, 7 [in Russian].

18. Babenko, A.N. (2009). Aksyolohycheskye prychynы pravotvorcheskykh oshybok. Pravotvorcheskye oshybky: poniatye, vydu, praktyka y tekhnyka ustranenyia v postsovetskykh hosudarstvakh : materyalы Mezhd. nauch.-prakt. kruhloho stola (Moskva, 29-30 maia 2008 h.). Moscow: Prospekt [in Russian].

19. Zamorska, L.I. (2009). Vidnosno vyznacheni normy prava: poniattia, struktura, funktsii. Extended abstract of candidate's thesis. Odesa [in Ukrainian].

20. Varych, O.H. (2006). Ekonomichni funktsii suchasnoi derzhavy: pryroda, zmist, tendentsii rozvytku v Ukraini. Extended abstract of candidate's thesis. Kyiv [in Ukrainian].

21. Sydorenko, O.O. (2014). Protsesualni normy prava: poniattia, osoblyvosti, riznovydy. Kharkiv: Pravo [in Ukrainian].

22. Tsvietkov, V.V., Horbatenko, V.P. (2001). Demokratiia - Upravlinnia - Biurokratiia: v konteksti modernizatsii ukrainskoho suspilstva. Kyiv: In-t derzhavy i prava im. V. M. Koretskoho NAN Ukrainy [in Ukrainian].

23. Tsvietkov, V.V., Selivanov, V.M., Skrypniuk, O.V. (2006). Derzhavne upravlinnia i polityka. Kyiv: Abrys [in Ukrainian].

24. Pohrebniak, S. (2008). Znachennia osnovopolozhnykh pryntsypiv prava dlia formuvannia i rozvytku pravovoi derzhavnosti. Visnyk Akademii pravovykh nauk Ukrainy, 3 (54), $92-93$ [in Ukrainian].

Sydorenko O. O., PhD in Law, The Department of Theory of State and Law, Assistant, Yaroslav Mudryi National Law University, Ukraine, Kharkiv.

e-mail : Sydorenko1200@gmail.com ; ORCID 0000-0003-0485-6431

\section{General-theoretical analysis of legal consciousness as a catalyst for the development of Ukraine's legal system}

The content of the concept of legal consciousness from the point of view of modern scientific developments on this issue is considered. The article is devoted to the analysis of the interrelations of the legal consciousness and the legal system in the context of the European integration processes in Ukraine. The conclusion is argued: the processes that occur in society inevitably affect the legal consciousness and the development of new branches of law. Further development of the legal system of Ukraine and its acquisition of qualitatively new properties that would contribute to the development of civil society in the state and the establishment of the rule of law are possible only in the context of the development of legal consciousness. The development of the legal system of Ukraine has traditionally been a priority area of modern science research in the theory of state and law. The system of law is the regulatory core of the emerging legal system, based on the legal ideology of a particular state and at the same time serving as the normative basis of behavior in the field of law. The dialectic of the components of legal reality is due to their reflection in human consciousness and the embodiment of this process in other legal phenomena. But at the same time, one should not abstract from the generative role of legal consciousness. A significant factor that raises the theoretical relevance of this topic is that the emphasis on the theoretical level was mostly given to the normative component of the legal system, which somewhat artificially pushed issues related to the development of justice into the background. However, the practice 
of law-making processes in Ukraine proved the need for special legal research on the relationship between the dynamics of legal consciousness and the development of the legal system as a whole. Realization of legal norms and increase of efficiency of legal regulation necessitate study of all factors that promote normal development of legal life of society and legal relations. One of them is the legal consciousness, since just as the functioning of the legal system is impossible without the subjects of law, and the existence of the subjects themselves can't be presented separately from the legal consciousness. Quite often, ineffectiveness and ineffectiveness of legal regulation are explained not only by the low level of legal acts in force, but also by the factor in rejecting the legal consciousness of the society of these legal norms or entire legal institutions. Legal consciousness is directly formed in the person himself and in fact with the person himself. She goes along with her path of development; in this context one can draw an analogy with the formation of the individual. And moreover, the person as the basis of the natural and social world, its development, forms the ideas of the legal field, that is, reflects through its legal consciousness the foundations of legal reality around them.

Keywords: legal consciousness, legal system, civil society, the system of law, the structure of the system of law, the subject of legal regulation, the method of legal regulation.

Надійшла до редколегії 15.05.2018 p. 